Asian J. Med. Biol. Res. 2020, 6 (2), 168-175; doi: 10.3329/ajmbr.v6i2.48047

\author{
Asian Journal of \\ Medical and Biological Research \\ ISSN 2411-4472 (Print) 2412-5571 (Online) \\ www.ebupress.com/journal/ajmbr
}

\title{
Article \\ Effects of Neem and Nishyinda leaves supplementation on growth performance and gut biosis in broiler
}

Atikur Rahaman, Md. Bazlar Rashid*, Md. Mahmudul Hasan, Rakibul Islam, Fahima Binthe Aziz and Sumon Sarkar

Department of Physiology and Pharmacology, Hajee Mohammad Danesh Science and Technology University, Dinajpur-5200, Bangladesh

*Corresponding author: Md. Bazlar Rashid, Department of Physiology and Pharmacology, Hajee Mohammad Danesh Science and Technology University, Dinajpur-5200, Bangladesh. Phone: +8801717353824; E-mail: bazlar116@gmail.com

Received: 22 March 2020/Accepted: 28 April 2020/ Published: 30 June 2020

\begin{abstract}
This study was conducted under the Department of Physiology and Pharmacology to determine the effects of Neem and Nishyinda leaves supplementation on growth performance and GUT biosis in broilers. A total of 40 day old broiler chicks were divided into four groups A, B, C and D. Group A was considered as control, fed only with commercial broiler ration. Group B supplemented with formulation of 2 gm grinded Neem leaves, Group C with 2 gm grinded Nishyinda leaves and Group D with 1 gm grinded Neem leaves plus 1 gm grinded Nishyinda leaves per liter of water respectively. Observations were recorded for live body weight, weight gain, feed consumption, feed efficiency, hemato-biochemical parameters and GUT biosis specially the parasite of birds in six weeks. Body weights were increased significantly $(\mathrm{p}<0.05)$ in all treated groups in respect to the control and highest was recorded in combine Neem plus Nishyinda supplemented groups (Group D). No significant ( $p>0.05$ ) differences were observed among the groups for PCV and TEC values. Hb content increased and ESR decreased significantly $(\mathrm{p}<0.05)$ with combine Neem plus Nishyinda supplemented group (Group D). The serum SGOT and SGPT levels were also decreased with the same kind of supplementation. In treatment group there was significantly decreased of parasitic eggs, but in case of control group no decrease of parasitic eggs. There was no significant pathological change in any internal organs of the broiler of treated groups. Best result was found in the group D. The present study reveals that combine supplementation of Neem plus Nishyinda gives better result over other groups in respect to body weight gain, feed conversion ratio, hemato-biochemical parameter and profitability without making any health hazard of the broilers.
\end{abstract}

Keywords: neem; nishyinda; gut biosis

\section{Introduction}

Bangladesh is an agricultural country. Bangladesh is also a highly populated country. Large amount of people depend on agriculture for their livelihood. Poultry sector is one of the branches of agriculture. Poultry production especially chickens and ducks has attained an important place in agricultural economy of Bangladesh both through contribution to GDP and employment especially in urban areas. About $80 \%$ of the total population of 160 million is living in the 68,000 villages of Bangladesh and almost each and every village home holds 6 to 7 chickens (Samad, 2005). From poultry people get egg, meat which fulfills the protein demand of huge amount of people of Bangladesh. There are so many sources of protein but it is not possible to fulfill the demand without broiler. Because the duration of broiler rearing is very short and within $36-42$ days it is ready for marketing and suitable for human consumption. It also brings very short time return to farmer. According to our socio-economic situation, the knowledge of our farmer is very little because most of them are not properly trained for broilers production. There are various Bacterial, Viral, Mycoplasmal, Fungal and Parasitic disease 
occurs in broiler, which increase the mortality rate, but unemployed young generation is coming in this business for short return of value and profit. Pharmaceutical companies take this advantage. They are convincing farmers for using antibiotics as a growth promoter or life savings for broiler. As a result, each and every broiler is a depot of antibiotics. When these broilers are consumed by human this antibiotic residue enters into human body and causing serious human health hazards with drug residues (Kibria et al., 2009). With the development and wide use of synthetic and semi-synthetic antibiotics, pros and cons have been experienced throughout the bacitracin, lincomycin, penicillin, chlortetracycline and virginiamycin promote growth because of an affects on the microflora in the gastrointestinal tract. Antimicrobial resistance in zoonotic enteropathogens including Salmonella, Escherichia coli, 50 years, which have been directed research back to natural antimicrobial products as indispensable resources. Consequently there is considerable research interest in the possible use of natural products, such as essential oils and extracts of edible and medicinal plants, herbs and spices, for the development of new additives in animal feeding. Enterococci in food animals is of special concern to human health because these bacteria are likely to transfer from the food chain to humans. So, scientists are again concentrating on the use of our ancient medicinal system to find beneficial herbs and plants, which can be safely used to increase the production. Such plants, Neem (Azadirachta indica) and Nishyinda (Vitex nigundo) are indigenous plant of Asian subcontinent known for its useful medicinal properties since ancient times. Neem and Nishyinda has attracted worldwide prominence due to its vast range of medicinal properties like antibacterial, antiviral, antifungal, antiprotozoal, hepato-protective and various other properties without showing any adverse affects (Greathead et al., 2003; Chowdhury et al., 2009). Also, Neem and Nishyinda promote growth and feed efficiency of birds, because of their antibacterial and hepatoprotective properties (Singh et al., 1996). The Neem tree Azadirachta indica from the family Meliaceae (Rai et al., 1997) contains azadirachtin- a biologically active compound found in its seeds, bark and leaves (Makeri et al., 2007) which is responsible for its varied medicinal uses (Schmutterer, 1990). Nishyinda (Vitex negundo) is a shrub that grows in the Philippines. The leaves of $V$. negundo possess discutients properties and are applied to rheumatic swellings of the joints. They may be applied locally to swellings from rheumatic arthritis. The juice of the leaves is used for the treatment of fetid discharges. The principal constituents of the leaf juice are casticin, isoorientin, chrysophenol D, luteolin, $\mathrm{p}-$ hydroxybenzoic acid and D-fructose. Neem (Azadirachia indica) and Nishyinda (Vitex nigundo) dry leaves extract as medical herbs could be beneficial in immunosuppressant diseases of poultry. Neem and Nishyinda leaves contain a vast array of chemically diverse and biologically active ingredients (Dorababu et al., 2006). Low dose of Neem leaves extract have an inhibitory action on wide spectrum of microorganisms (Talwar et al., 1997) and immune modulator actions that induce cellular immune reaction (Devakumar and Suktt, 1993). Also, Craig et al., 1999 stated that several herbs could help providing some protection against bacteria and stimulate the immune system. By realizing all sorts of problem we are planning to rear broiler by using herbal medication instead of any antibiotics, to avoid human health hazards as well as economic broiler production to sustain small scale broiler farming in Bangladesh. This study was performed to observe the following specific objectives:

(i) To observe the growth performance and profit of broilers by grinded plant leaves supplementation.

(ii) To evaluate hemato-biochemical parameter in relation to that supplementation.

(iii) To observe the GUT biotic environment by observing parasites of broilers.

\section{Materials and Methods}

\subsection{Statement of the experiment}

The experiment was accomplished under the Department of Physiology and Pharmacology, Faculty of Veterinary and Animal Science of Hajee Mohammed Danesh Science and Technology University, Dinajpur.

\subsection{Experimental design}

All the 40 chicken randomly divided into 4 groups (A, B, C and D) for assessing the efficacy of grinded plants leaves as growth promoter on broilers.

Chickens of group 'A': was kept as control and was not treated.

Chickens of group 'B': was treated with grinded Neem leaves @ 2 gm in 1 liter water for consecutive six weeks. Chickens of group ' $\mathrm{C}$ ': was treated with grinded Nishyinda leaves@ 2 gm in 1 liter water for consecutive six weeks.

Chickens of group 'D': was treated with 1 gm grinded Neem leaves plus 1 gm grinded Nishyinda leaves in 1 liter water for consecutive six weeks.

All the broiler of treated and control groups were closely observed for 42 days and following parameter were studied: 


\subsection{Collection of plant leaves}

Neem and Nishyinda leaves were selected for effectiveness as growth promoter on broiler. Mature and disease free Neem and Nishyinda leaves were collected from tree.

\subsection{Preparation of grinded leaves for supplementation}

Mature and disease free leaves were collected. After collection, leaves were washed in water and cut into small pieces. Then fine grind was made by using pestle and morter, $2 \mathrm{gm}$ grinded leaves ware mixed with 1 liter of water and stored in refrigerator for further use.

\subsection{Collection and management of broiler chicks}

Broiler chicks collected from local market. The finally selected 40 chickens were allowed to acclimatize for 7 days in the experimental shed. The body weights of assigned chickens were taken with digital weight balance and the results were recorded. During acclimatization recommended feed and water supplied to the chicken.

\subsection{Clinical examination}

(i) The effect of the Neem, Nishyinda and Neem plus Nishyinda grinded leaves on body weight, feed consumption was recorded.

(ii) Chickens under trial and control groups were weighed in weighing balance.

\subsection{Hematological test}

Blood samples were collected from neck vein of broiler of both control and treated groups in day 21 and day 42 to study the effect of the Neem, Nishyinda and Neem plus Nishyinda grinded leaves and the following parameters were observed:
(a) Total erythrocyte count (TEC)
(b) Hemoglobin estimation (Hb)
(c) Packed cell volume (PCV)
(d) Erythrocyte sedimentation rate (ESR)

\subsection{Biochemical test}

- Serum Glutamic Pyruvic Transaminase (SGPT) or Alanine Amino Transferase (ALT)

- Serum Glutamic Oxaloacetic Transaminase (SGOT) or Aspertate Amino Transferase (AST)

\subsection{Postmortem examination for side effect}

Two broilers from every group were slaughtered to see if there were any pathological changes present in day 21 and day 42 of treatment. There was no significant pathological change in any internal organs of the broiler of treated groups.

\subsection{Statistical analysis}

The data were analyzed statistically between control and treated groups of broiler by the analysis of variance (ANOVA) technique in completely randomized design.

\section{Results and Discussion}

This experiment was conducted to study the efficacy of grinded Neem (Azadirachta indica) and grinded Nishyinda (Vitex nigundo) leaves as a growth promoter in broiler and was held under the Department of Physiology and Pharmacology. 40 day old chicks were randomly divided into 4 groups (A, B, C and D) for assessing the efficacy of grinded plants leaves as growth promoter on broilers. The experimental units were kept on a floor litter system in separate pens. Equal amount of ration was offered to the birds twice a day and left over feed was collected to calculate feed consumption of the birds. Fresh and clean water was available at all the time. The experiment was conducted according to the completely randomized design and data about final body weight, weight gain, feed consumption and mortality were recorded during the experimental period (1-6 weeks of age).

\subsection{Body weight}

Body weights of different groups of birds are presented in Table 1. Broiler treated with Neem, Nishyinda and Neem plus Nishyinda supplementation showed an increased body weight gain than control group (without treatment). 
Table 1. Initial and final live weight, weight gain, feed consumption and feed conversion ratio of broilers fed at different levels of grinded Neem and grinded Nishyinda leaves from 1 to 6 weeks of age.

\begin{tabular}{|c|c|c|c|c|c|}
\hline Groups & $\begin{array}{llr}\text { Initial } & \text { live } \\
\text { weight } & (\mathrm{gm}) & \text { on } \\
\text { day } 7 & & \end{array}$ & $\begin{array}{l}\text { Final live weight } \\
\text { (gm) on day } 42\end{array}$ & Weight gain (gm) & $\begin{array}{l}\text { Feed consumption } \\
\text { (gm) }\end{array}$ & $\begin{array}{l}\text { Feed conversion } \\
\text { ratio (gm feed } \\
\text { consumed/gm } \\
\text { weight gain) }\end{array}$ \\
\hline $\mathrm{A}$ & $167.00 \mathrm{a} \pm 2.00$ & $1610.00 \mathrm{~d} \pm 10.00$ & $1443.00 \mathrm{~d} \pm 8.00$ & $3000.00 \mathrm{~d} \pm 0.00$ & $2.0750 \mathrm{a} \pm 0.015$ \\
\hline $\mathrm{B}$ & $166.00 \mathrm{a} \pm 4.00$ & $1830.00 \mathrm{~b} \pm 10.00$ & $1664.00 \mathrm{~b} \pm 6.00$ & $3250.00 \mathrm{~b} \pm 0.00$ & $1.985 \mathrm{bc} \pm 0.025$ \\
\hline $\mathrm{C}$ & $169.00 \mathrm{a} \pm 2.00$ & $1720.00 \mathrm{c} \pm 15.00$ & $1551.00 \mathrm{c} \pm 13.00$ & $3100.00 \mathrm{c} \pm 0.00$ & $1.995 b \pm 0.015$ \\
\hline $\mathrm{D}$ & $168.00 \mathrm{a} \pm 0.00$ & $1910.00 \mathrm{a} \pm 5.00$ & $1742.00 \mathrm{a} \pm 5.00$ & $3350.00 \mathrm{a} \pm 0.00$ & $1.915 \mathrm{c} \pm 0.005$ \\
\hline
\end{tabular}

Note: Values followed by same superscripts in the same column are not statistically significant $(\mathrm{p}>0.05)$, different superscripts indicate that difference is significant $(\mathrm{P}<0.05)$. In this and other tables, $\mathrm{A}=$ control (without treatment), $\mathrm{B}=2 \mathrm{gm}$ grinded Neem leaves, $\mathrm{C}=2 \mathrm{gm}$ grinded Nishyinda leaves, $\mathrm{D}=1 \mathrm{gm}$ grinded Neemplus1gm grinded Nishyinda leaves.

Table 1 revealed that-

In Group A initial live wt. 167 gm, final live wt. 1610 gm, weight gain 1443 gm and feed conversion ratio (FCR) 2.07

In Group B initial live wt. 166 gm, final live wt. 1830 gm, weight gain 1664 gm and FCR 1.95

In Group C initial live wt. 169 gm, final live wt. 1720 gm, weight gain 1551 gm and FCR 1.99

In Group D initial live wt. 168 gm, final live wt. 1910 gm, weight gain 1742 gm and FCR 1.92

The birds of group D using ration supplemented with grinded $1 \mathrm{gm}$ Neem plus grinded $1 \mathrm{gm}$ Nishyinda leaves utilized their feed statistically significantly $(\mathrm{P}<0.05)$ more efficiently among the other groups.

The birds using ration supplemented with (1 gm Neem plus $1 \mathrm{gm}$ Nishyinda) (Group D) leaves gained the highest live weight among the other groups and it is significant at 5\% $(\mathrm{p}<0.05)$ level. Supplementation of grinded Neem plus Nishyinda (D) leaves in the treatment caused improvement in the feed efficiency as compared to that of other group. Similarly, Nemade and Kukde (1993) reported increase in feed efficiency in Neem and Nishyinda fed groups, which is in agreement with the findings of the present study.

\subsection{Dressing percentage and relative giblet weight}

Dressing percentage and relative giblet weight of different groups of birds are presented in (Table 2). There was no significant different of all the groups.

Table 2. Dressing percentages, relative giblet weight (heart, gizzard, liver and spleen) and pancreas weight of broilers fed at different levels of grinded Neem and grinded Nishyinda leaves from 1-6 weeks of age.

\begin{tabular}{|l|l|l|l|l|l|l|}
\hline Groups & $\begin{array}{l}\text { Dressing } \\
\text { percentage }\end{array}$ & $\begin{array}{l}\text { Relative heart } \\
\text { weight }(\mathbf{g m})\end{array}$ & $\begin{array}{l}\text { Relative } \\
\text { gizzard } \\
\text { weight(gm) }\end{array}$ & $\begin{array}{l}\text { Relative liver } \\
\text { weight (gm) }\end{array}$ & $\begin{array}{c}\text { Relative } \\
\text { spleen weight } \\
\text { (gm) }\end{array}$ & $\begin{array}{l}\text { Relative } \\
\text { pancreas } \\
\text { weight (gm) }\end{array}$ \\
\hline $\mathrm{A}$ & $63.57 \mathrm{~b} \pm 1.010$ & $0.47 \mathrm{~b} \pm 0.040$ & $1.42 \mathrm{c} \pm 0.100$ & $2.57 \mathrm{c} \pm 0.045$ & $0.13 \mathrm{~b} \pm 0.005$ & $0.26 \mathrm{c} \pm 0.025$ \\
\hline $\mathrm{B}$ & $65.68 \mathrm{ab} \pm 0.505$ & $0.57 \mathrm{~b} \pm 0.050$ & $1.68 \mathrm{~b} \pm 0.020$ & $2.78 \mathrm{~b} \pm 0.045$ & $0.17 \mathrm{ab} \pm 0.010$ & $0.34 \mathrm{ab} \pm 0.005$ \\
\hline $\mathrm{C}$ & $64.34 \mathrm{~b} \pm 1.005$ & $0.56 \mathrm{~b} \pm 0.015$ & $1.61 \mathrm{~b} \pm 0.030$ & $2.73 \mathrm{~b} \pm 0.025$ & $0.15 \mathrm{ab} \pm 0.005$ & $0.30 \mathrm{bc} \pm 0.005$ \\
\hline $\mathrm{D}$ & $67.14 \mathrm{a} \pm 0.285$ & $0.71 \mathrm{a} \pm 0.025$ & $1.97 \mathrm{a} \pm 0.010$ & $2.91 \mathrm{a} \pm 0.030$ & $0.20 \mathrm{a} \pm 0.010$ & $0.38 \mathrm{a} \pm 0.015$ \\
\hline
\end{tabular}

Note: Values followed by same superscripts in the same column are not statistically significant $(p>0.05)$, different superscripts indicate that difference is significant $(\mathrm{P}<0.05)$.

- Relative weight $(\mathrm{gm})=$ Weight of organ/ Live body weight of bird X 100

- Dressing \%= Dress weight of bird/Live weight of bird X 100

Table 2 revealed that-

Statistical analysis of the data did not show any difference $(\mathrm{P}<0.5)$ between the dressing percentages of the birds of different feeding groups. 
Statistical analysis of the data did not show any difference between the relative gizzard weights of the birds of different feeding groups.

Statistical analysis of the data did not show any difference between the relative spleen weight of the birds of different feeding groups using ration with or without supplementation of Neem and Nishyinda leaves.

\subsection{Economics of Production:}

Cost of different groups of bird is presented in (Table 3).

Table 3. Data showing economics of broiler production kept under different treatment groups from day old chick to 6 weeks of age.

\begin{tabular}{|l|l|l|l|l|}
\hline Description & A & B & C & D \\
\hline Cost/chick (Taka) & 46.00 & 46.00 & 46.00 & 46.00 \\
\hline Average feed consumed (Kg)/chicks/42 days & 3.000 & 3.250 & 3.100 & 3.350 \\
\hline Feed price/kg (Taka) & 44.50 & 44.50 & 44.50 & 44.50 \\
\hline Cost of herbal growth promoters (Taka) & 0.00 & 2.00 & 2.00 & 2.00 \\
\hline Total feed cost (Taka)/Broiler & 133.50 & 146.62 & 139.95 & 151.07 \\
\hline Miscellaneous cost ( Taka) & 10.00 & 10.00 & 10.00 & 10.00 \\
\hline Total cost/Broiler (Taka.) & 189.50 & 202.62 & 195.95 & 207.07 \\
\hline Average live weight (Kg)/Broiler & 1.610 & 1.830 & 1.720 & 1.910 \\
\hline Sale price/Kg live wt. (Taka.) & 135.00 & 135.00 & 135.00 & 135.00 \\
\hline Sale price/broiler (Taka) & 217.35 & 247.05 & 232.20 & 257.85 \\
\hline Net profit/broiler (Taka.) & 27.85 & 44.42 & 36.25 & 50.78 \\
\hline Profit/ Kg live weight (Taka) & 17.29 & 24.27 & 21.07 & 26.58 \\
\hline
\end{tabular}

Table 3 revealed that-

The average rearing costs of broiler are kept under different treatment groups viz. A, B, C, D was $189.50 \mathrm{Tk}$, 202.62 Tk, 195.95 Tk and 207.07 Tk respectively. Miscellaneous cost summed up Tk 10 per broiler, which included the estimated cost of electricity cost of labor, litter, disinfectant. The average live weight/broiler in group A, B, C and D was $1.610 \mathrm{~kg}, 1.830 \mathrm{~kg}, 1.720 \mathrm{~kg}$ and $1.910 \mathrm{~kg}$ respectively. The broiler was sold in live weight basis at the rate of Tk $135 / \mathrm{kg}$. The net profit $/ \mathrm{Kg}$ live weight in the respective group was found to be taka 17.29, 24.27, 21.07 and 26.58 respectively. The level of Neem and Nishyinda grinded leaves used in the ration exhibited their effect on the profit margin of the broiler.

\subsection{Hematological and biochemical parameter}

Table 4. Study of grinded Neem and Nishyinda leaves on hematological and biochemical parameter of broiler on day 21 .

\begin{tabular}{|c|c|c|c|c|c|c|}
\hline Groups & $\begin{array}{l}\text { TEC } \\
\left(\text { million/mm }{ }^{3}\right) \\
(\text { Mean } \pm \mathrm{SEM})\end{array}$ & $\begin{array}{l}\text { Hb } \quad(\text { gm/dl }) \\
(\text { Mean } \pm \text { SEM })\end{array}$ & $\begin{array}{l}\text { PCV }(\%) \\
(\text { Mean } \pm \text { SEM) }\end{array}$ & $\begin{array}{ll}\text { ESR } & \left(\mathrm{mm} / 1^{\text {st }}\right. \\
\text { hour }) & (\text { Mean } \\
\pm \text { SEM }) & \\
\end{array}$ & $\begin{array}{l}\text { SGPT (IU/L) } \\
\text { (Mean } \pm \\
\text { SEM) } \\
\end{array}$ & $\begin{array}{l}\text { SGOT } \quad(\text { IU/L }) \\
(\text { Mean } \pm \text { SEM })\end{array}$ \\
\hline $\mathrm{A}$ & $189.30 \mathrm{~b} \pm 0.600$ & $5.925 \mathrm{c} \pm 0.08$ & $15.38 \mathrm{c} \pm 0.125$ & $10.86 \mathrm{a} \pm 0.195$ & $24.55 \mathrm{a} \pm 0.350$ & $28.13 \mathrm{a} \pm 0.175$ \\
\hline $\mathrm{B}$ & $194.50 \mathrm{a} \pm 0.400$ & $6.39 \mathrm{a} \pm 0.04$ & $17.95 \mathrm{a} \pm 0.350$ & $8.69 \mathrm{c} \pm 0.110$ & $24.00 \mathrm{ab} \pm 0.100$ & $26.32 b c \pm 0.575$ \\
\hline $\mathrm{C}$ & $190.79 b \pm 0.59$ & $6.15 b \pm 0.10$ & $16.69 \mathrm{~b} \pm 0.515$ & $9.40 \mathrm{~b} \pm 0.200$ & $23.32 b \pm 0.375$ & $27.22 \mathrm{ab} \pm 0.125$ \\
\hline $\mathrm{D}$ & $195.995 \mathrm{a} \pm 0.33$ & $6.42 \mathrm{a} \pm 0.04$ & $18.89 \mathrm{a} \pm 0.110$ & $8.48 c \pm 0.125$ & $22.18 \mathrm{c} \pm 0.320$ & $25.95 \mathrm{c} \pm 0.150$ \\
\hline
\end{tabular}

Note: Values followed by same superscripts in the same column are not statistically significant $(p>0.05)$, different superscripts indicate that difference is significant $(\mathrm{P}<0.05)$. 
Table 5. Study of grinded Neem and Nishyinda leaves on hematological and biochemical parameter of broiler on day 42 .

\begin{tabular}{|c|c|c|c|c|c|c|}
\hline Groups & $\begin{array}{lc}\text { TEC } & (\text { million/ } \\
\left.\text { mm }^{3}\right) & (\text { Mean } \pm \\
\text { SEM) } & \\
\end{array}$ & $\begin{array}{l}\text { Hb } \quad(\mathbf{g m} / \mathbf{d l}) \\
(\text { Mean } \pm \\
\text { SEM) }\end{array}$ & $\begin{array}{l}\text { PCV }(\%) \\
(\text { Mean } \pm \text { SEM) }\end{array}$ & $\begin{array}{l}\text { ESR } \quad\left(\mathbf{m m} / 1^{\text {st }}\right. \\
\text { hour }) \quad(\text { Mean } \\
\pm \text { SEM }) \\
\end{array}$ & $\begin{array}{l}\text { SGPT (IU/L) } \\
(\text { Mean } \pm \\
\text { SEM) }\end{array}$ & $\begin{array}{l}\text { SGOT (IU/L) } \\
(\text { Mean } \pm \\
\text { SEM) }\end{array}$ \\
\hline A & $237.48 \mathrm{~d} \pm 1.125$ & $6.80 \mathrm{~d} \pm 0.050$ & $15.98 \mathrm{~d} \pm 0.145$ & $11.81 \mathrm{a} \pm 0.245$ & $27.03 a \pm 0.205$ & $30.44 \mathrm{a} \pm 0.335$ \\
\hline $\mathrm{B}$ & $291.02 b \pm 0.885$ & $8.04 \mathrm{~b} \pm 0.115$ & $21.46 \mathrm{~b} \pm 0.155$ & $7.64 c \pm 0.160$ & $22.54 c \pm 0.365$ & $24.39 \mathrm{c} \pm 0.265$ \\
\hline $\mathrm{C}$ & $285.01 \mathrm{c} \pm 0.110$ & $7.13 c \pm 0.020$ & $19.19 \mathrm{c} \pm 0.015$ & $9.40 \mathrm{~b} \pm 0.200$ & $23.88 b \pm 0.075$ & $26.28 b \pm 0.175$ \\
\hline $\mathrm{D}$ & $295.74 \mathrm{a} \pm 0.585$ & $8.74 \mathrm{a} \pm 0.085$ & $22.930 \mathrm{a} \pm 0.745$ & $6.38 \mathrm{~d} \pm 0.245$ & $21.43 \mathrm{~d} \pm 0.025$ & $25.11 \mathrm{c} \pm 0.005$ \\
\hline
\end{tabular}

Note: Values followed by same superscripts in the same column are not statistically significant ( $>0.05)$, different superscripts indicate that difference is significant $(\mathrm{P}<0.05)$.

\subsubsection{Hematological parameter}

\section{A. Total erythrocyte count (million/ $\mathrm{mm}^{3}$ )}

Total erythrocyte count is presented in Tables 4 and 5 in day 21 and in day 42 . The values of TEC in all treated groups and control group were more or less similar and the values were within the normal range. The highest TEC was recorded in Group D and lowest in Group A. Although these values show a little fluctuation they were not statistically significant $(\mathrm{p}>0.05)$.

\section{B. Estimation of hemoglobin (gm/dl)}

Hemoglobin content is presented in Tables 4 and 5 in day 21 and in day 42 . The values of $\mathrm{Hb}$ in all treated groups and control group were more or less similar and the values were within the normal range. The highest $\mathrm{Hb}$ was recorded in Group D and lowest in Group A. All the data were statistically significant $(\mathrm{p}<0.05)$.

\section{Packed cell volume (\%)}

Packed cell volume is presented in Tables 4 and 5 in day 21 and in day 42 . The values of PCV in all treated groups and control group were more or less similar and the values were within the normal range. The highest PCV was recorded in Group D and lowest in Group A. Although these values show a little fluctuation they were statistically significant $(\mathrm{p}<0.05)$.

\section{Erythrocyte Sedimentation Rate $\left(\mathrm{mm} / \mathbf{1}^{\text {st }}\right.$ hour $)$}

Erythrocyte sedimentation rate content is presented in Tables 4 and 5 in day 21 and in day 42 . The values of ESR in all treated groups and control group were more or less similar and the values were within the normal range. The highest ESR was recorded in Group A and lowest in Group D. Although these values show a little fluctuation they were not statistically significant $(\mathrm{p}>0.05)$.

This study has revealed that there is an inverse relationship between grinded Neem plus Nishyinda (D) leaves doses and on the body weight (Table 1) and also on the hematological effects in broiler (Tables 4 and 5). This agrees with Nagalakshmi et al. (1996) and Gowda et al. (1998) that Neem plus Nishyinda bitters possess a strong influence on hematological traits particularly PCV and $\mathrm{Hb}$ of subjects, depending on their nutritional status. The performance of birds fed Neem plus Nishyinda (D) showed significantly better performance as compared to the other group. These results coincide with those of Chakravarty and Prasad (1991) who achieved highest body weight gain and best feed conversion ratio as compared to control when offered Neem plus Nishyinda (D) leaves extract to broilers from 1 to 6 weeks.

\subsubsection{Biochemical parameter}

\section{A. Serum glutamic pyruvic transaminase (IU/L)}

SGPT level is presents in Tables 4 and 5 in days 21 and days 42. The values of SGPT in all treated groups and control group were more or less similar and the values were within the normal range. The highest SGPT was recorded in Group A and lowest in Group D. Although these values show a little fluctuation they were statistically significant $(\mathrm{p}<0.05)$. 
B. Serum glutamic oxaloacetic transaminase (IU/L)

SGOT level is presented in Table 4 in days 21 and days 42. The values of SGOT in all treated groups and control group were more or less similar and the values were within the normal range. The highest SGOT was recorded in Group A and lowest in Group D. Although these values show a little fluctuation they were statistically significant $(\mathrm{p}<0.05)$.

The greatly reduced SGPT and SGOT titer level as observed in the present study implies good health condition with less damage of muscle cell.

\section{Conclusions}

Forty healthy commercial broilers were equally divided into four groups $(n=10)$ to carry out this research work. In this experiment, grinded Neem and Nishyinda leaves were studied in terms of growth promoter on broilers because we showed that these herbal plants are available, cost effective and produced broilers are free from any drug residual effect and suitable for human consumption. In this research work, the continuous treatment with grinded Neem (Azadirachta indica) and grinded Nishyinda (Vitex negundo) leaves produced a significant $(\mathrm{p}<0.05)$ increased of the live body weight. It is concluded that supplementation of $1 \mathrm{gm}$ grinded Neem plus $1 \mathrm{gm}$ grinded Nishyinda (D) leaves per liter water of treatment groups caused significant increase in live body weight and feed efficiency as compared to that of other groups of broilers. From this experiment we found that, between the control group and the treatment group of birds, the Neem plus Nishyinda (D) groups are more profitable than any other groups. Hemoglobin content significantly $(\mathrm{p}<0.01)$ increased and ESR content significantly $(\mathrm{p}<0.05)$ decreased with Neem plus Nishyinda (D) supplementation. No significant $(\mathrm{p}>0.05)$ differences were observed among the treatment groups in case of PCV and TEC values in respect to the control group after treatment. The SGOT level was decreased significantly $(\mathrm{p}<0.05)$ with grinded Neem plus grinded Nishyinda (D) leaves and SGPT level was also decreased with the same kind of supplementation, but both SGOT and SGPT level increased in case of control (A) group. We also found that, in the treatment groups there is significant decrease of parasitic eggs, but in case of control group there is increase of parasitic eggs. There was no significant pathological change in any internal organs of the broiler of treated groups. From the present field and laboratory trial, it can be concluded that combine supplementation of $1 \mathrm{gm}$ Neem plus $1 \mathrm{gm}$ Nishyinda (D) per liter water is highly beneficial for broiler growth without making any potential hazards of broiler and our formulations could be used as an alternative to growth promoters. Further studies are necessary to see any adverse effect in relation to histopathology before making a definite conclusion.

\section{Conflict of interest}

None to declare.

\section{References}

Chakravarty A and J Prasad, 1991. Study on the effect of neem leaf extract and neem and cake extract on the performance of broiler chicks. Ind. Poult. Advis., 24: 37-38.

Chowdhury, RR Deshpande, AA Zanzad, BN Ramteke, PE Taksande, RD Lanjewar and TR Gawande, 2009. Effect of dietary supplementation of Tulsi (Ocimum sanctum) leaf extract on egg yolk cholesterol and serum lipid profile in layers. Indian Journal of Field Veterinarians, 4: 30-33.

Craig WJ, 1999. Health-promoting properties of common herbs. Am. J. Clin. Nutr., 70: 491-499.

Devakumar C and DV Suktt, 1993. Chemistry, In: Randhawa NS \& Parmar BS (eds), neem research and development. 63-96.

Dorababu M, Mc Joshi, G Bhawani, Mm Kumar, A Chaturvedi and Rk Goel, 2006. Effect of aqueous extract of Neem (Azadirachta indica) leaves on offensive and diffensive gastric mucosal factors in rats. Indian Physiol. Pharmacol., 50: 241-249.

Gowda SK, SVS Verma, AV Elangovan and AD Singh, 1998. Neem (Azadirachta indica) kernel meal in the diet of white leghorn layers. Br. Poult. Sci., 39: 648-652.

Greathead H, 2003. Plants and plant extracts for improving animal productivity. Proc. Nutr.Soc., 62: 279-290.

Kibria ASMG, MA Awal, M Mostofa, AKM Saifuddin, MR Alam and MA Asgar, 2009. Detection of tetracycline residues in broilers of Chittagong. J. Environ. Sci. and Natural Resources, 2: 41-44.

Makeri HK, VA Maikai and JA Nok, 2007. Effect of topical application of Neem seed (Azadirachta indica) extract on sheep infested with Amblyomma variegatum. Afr. J. Biotechnol., 6: 2324-2327.

Nagalakshmi D, VRB Sastry, DK Agrawal, RC Ketiyar and SVS Verma, 1996. Performance of broiler chicks fed on alkali-treated Neem (Azadirachta indica) kernel cake as a protein supplement. Br. Poult. Sci., 37: 809818. 
Nemade PP and RJ Kukde, 1993. Effect of Neem leaf extract on broiler performance. Indian Poult. Rev., 24: 30-32.

Rai V, U Iyer and UV Mani, 1997. Effect of Tulasi (Ocimum sanctum) leaf extract supplementation on blood sugar levels, serum lipids and tissues lipids in diabetic rats, Plant Foods for Human Nutrition (Formerly Qualitas Plantarum) Volume 50, Number 1, 9-16.

Samad MA, 2005. Poultry Science and Medicine, LEP Publication, Mymensingh, Bangladesh. Pp. 504-508.

Schmutterer H, 1990. Properties and potential of natural pesticides from the neem tree, Azadirachta indica. Annu. Rev. Entomol., 35: 271-297.

Singh S, DK Majumdar and MR Yadav, 1996. Chemical and pharmacological studies on fixed oil of $O$. sanctum. Indian J. Exp. Biol., 34: 1212-1215.

Talwar GPP, RAS Raguvanshi, Mukherjee and S Shah, 1997. Plant immunomodulators for termination of unwanted pregnancy and contraception and reproductive health. Immunology and Cell Biology, 75: 190-192. 